\title{
Research
}

\section{Assessing an Adaptive Cycle in a Social System under External Pressure to Change: the Importance of Intergroup Relations in Recreational Fisheries Governance}

\author{
$\underline{\text { Katrin Daedlow }}^{1,2}, \underline{\text { Volker Beckmann }}^{1,3}$, and $\underline{\text { Robert Arlinghaus }}^{2,4}$
}

\begin{abstract}
The adaptive cycle constitutes a heuristic originally used to interpret the dynamics of complex ecosystems in response to disturbance and change. It is assumed that socially constructed governance systems go through similar phases $(K, \Omega$ [omega], $\alpha$ [alpha], $r$ ) as evident in ecological adaptive cycles. Two key dimensions of change shaping the four phases of an adaptive cycle are the degree of connectedness and the range of potential in the system. Our purpose was to quantitatively assess the four phases of the adaptive cycle in a social system by measuring the potential and connectedness dimensions and their different levels in each of the four phases. We assessed these dimensions using quantitative data from content analysis of magazine articles describing the transition process of East German recreational fisheries governance after the fall of the Berlin Wall in 1989. This process was characterized by the discussion of two governance alternatives amendable for implementation: a central East German and a decentralized West German approach. Contrary to assumptions in the adaptive cycle heuristic, we were unable to identify the four phases of the adaptive cycle in our governance system based on quantitatively assessed levels of connectedness and potential alone. However, the insertion of in-group (East Germans) and out-group (West Germans) dimensions representing the two governance alternatives in our analysis enabled us to identify the specific time frames for all four phases of the adaptive cycle on a monthly basis. These findings suggest that an unmodified "figure-eight model" of the adaptive cycle may not necessarily hold in social systems. Inclusion of disciplinary theories such as intergroup relation theory will help in understanding adaptation processes in social systems.
\end{abstract}

Key Words: adaptive cycle; connectedness; content analysis; East Germany; intergroup relation theory; potential; recreational fisheries; social system

\section{INTRODUCTION}

Recreational fisheries governance in East Germany was under enormous external pressure to change after the fall of the Berlin Wall in November 1989. The following reunification process of East and West Germany disrupted the entire social and political system in East Germany, which was developed in the former German Democratic Republic (GDR). In particular, the large-scale fisheries management system of the GDR, in which a large number of water bodies were centrally governed by one nation-wide angler association, was at risk of being dissolved when the sociopolitical and economic environment rapidly altered from a centrally planned to a social market economy with a democratic constitution after the reunification with the Federal Republic of Germany (FRD). A decentralized recreational fisheries governance alternative existed in the FRD (West Germany) and was available to be implemented in the East. This alternative was characterized by locally self-organized angling clubs, which usually govern a small set of fisheries on a restricted number of local water bodies. A policy discussion and negotiation process started with the proactive participation of East German recreational fisheries managers. As a result, the central governance approach persisted in most parts of East Germany, despite the window of opportunity for angling clubs

\footnotetext{
${ }^{1}$ Division of Resource Economics, Humboldt-Universität zu Berlin, Germany, ${ }^{2}$ Leibniz-Institute of Freshwater Ecology and Inland Fisheries Berlin, Germany, ${ }^{3}$ Landscape Economics Group, Ernst Moritz Arndt University Greifswald, Germany, Inland Fisheries Management Laboratory, HumboldtUniversität zu Berlin, Germany
} 
to obtain independence in governance and management of local water bodies. This phenomenon attracted our interest because we wanted to evaluate whether the social system of East German recreational fisheries governance went through distinct phases of change amendable to the adaptive cycle heuristic (Holling and Gunderson 2002).

The adaptive cycle was originally conceptualized by Holling $(1986,2001)$ to interpret the dynamics of complex ecosystems in response to disturbance and change (Fig. 1). In terms of its dynamics, the adaptive cycle has been described as moving slowly from exploitation $(r)$ to conservation $(K)$, maintaining the conservation stage for a prolonged period, then developing very rapidly from $K$ to release $(\Omega)$, continuing rapidly to reorganization $(\alpha)$ and back to exploitation ( $r$; Holling and Gunderson 2002). Depending on the particular configuration of the system, the system can then begin a new adaptive cycle or alternatively it might transform into a new configuration, shown as an exit arrow in the popular "figure eight model" (Fig. 1). The adaptive cycle, which is one of five heuristics used to understand social-ecological system (SES) behavior (Walker et al. 2006), the other four heuristics being resilience, panarchy, transformability, and adaptability, is of considerable conceptual appeal, and it is claimed to be generally applicable to ecological and social systems as well as to coupled social-ecological systems (Gunderson et al. 2002).

For social systems, the adaptive cycle has been characterized by Holling and Gunderson (2002) as follows: in the phase of conservation $(K)$ the system is hierarchically consolidated by tight organization and control, which precludes management or policy alternatives. In case of internal or external disturbances, the system progresses toward destruction $(\Omega)$, and the loss of control leads to the release of the accumulated capital, e.g., money, skills, mutual trust, and experience in organizations. In the following $\alpha$ phase, a competition among entrepreneurial pioneers and/or surviving leaders occurs and leads to the reorganization of the system. In this phase, humans have the greatest chance for innovation and change. However, if the system and its entrepreneurial pioneers do not have the capacity to deal with the disturbance, the system will transform into a different configuration and enter a new adaptive cycle. If the system is resilient, i.e., capable of controlling the disturbance, the cycle proceeds to the exploitation phase $(r)$ when a policy plan is chosen among the various alternatives discussed during the $\alpha$ phase. In the $r$ phase a progression toward the next $K$ phase occurs as the winners of the political game restructure processes and policies for conservation. At this stage the system evolves into a $K 2$ phase with ongoing functions and controls similar to those of the original $K$ phase $(K 1)$. The succession of the four phases is assumed to be generally applicable to all social systems (Gunderson et al. 2002) and thus, should have occurred also after the disturbance of East German recreational fisheries governance in 1989.

The two salient dimensions determining change in an adaptive cycle are connectedness and potential (Holling and Gunderson 2002). The connectedness dimension, represented by the horizontal axis in the visual depiction of the adaptive cycle (Fig. 1), stands for the ability of a system to internally control its own destiny (Holling 2001). It "reflects the strength of internal connections that mediate and regulate the influences between inside processes and the outside world - essentially the degree of internal control that a system exerts over external variability" (Holling and Gunderson 2002:50). The potential dimension, represented by the vertical axis of the cycle (Fig. 1), stands for the "inherent potential of a system that is available for change" (Holling 2001:393). Social or cultural potential can be characterized by the "accumulated networks of relationships - friendship, mutual respect, and trust among people and between people and institutions of governance" (Holling and Gunderson 2002:49). Furthermore, potential can be thought of as the range of accumulated resources such as knowledge, inventions, and skills that are available and accessible. According to the adaptive cycle heuristic, the levels of both dimensions differ during the course of the cycle along the four phases (Fig. $1)$. The adaptive cycle heuristic thus predicts that the four phases of the cycle can be distinguished based on distinct combinations of high or low potential and connectedness.

The objective of this study was to quantitatively assess the four phases of the adaptive cycle by measuring the potential and connectedness dimensions and their respective levels in the social system of East German recreational fisheries governance while undergoing transition and change. For the purpose of this study, we defined the structure of recreational fisheries governance as the arrangement of property rights holders and fisheries regulations for inland recreational fisheries 
Fig. 1. The adaptive cycle (Gunderson and Holling 2002:34) shows the four phases of adaptation along the connectedness and potential dimensions. (+) indicates high level and (-) indicates low level of connectedness and potential. Figure was adapted from: Panarchy: understanding transformations in human and natural systems. by Lance H. Gunderson and C.S. Holling, editors. Copyright (C) 2002 Island Press. Reproduced by permission of Island Press, Washington, D.C., USA.

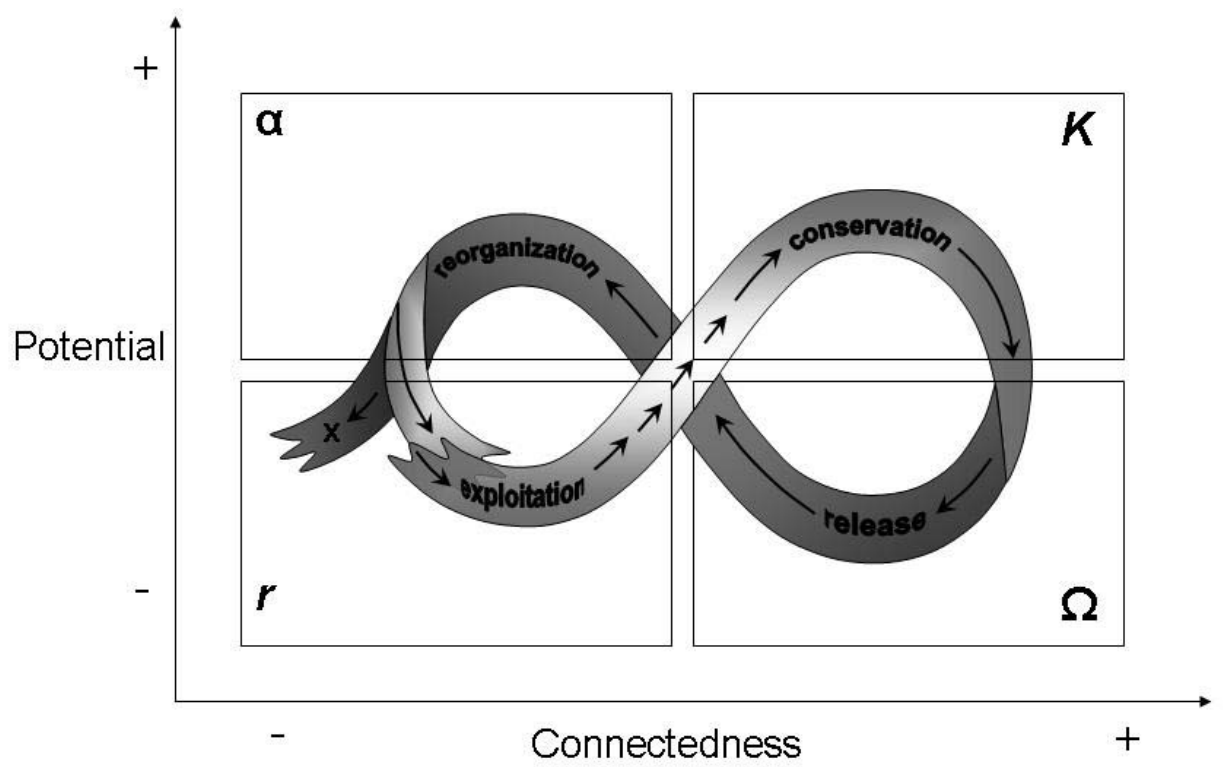

in Germany. Holders of property rights for inland fisheries in Germany usually have both the right to catch fish and the duty to manage the resource sustainably (Arlinghaus 2006, Daedlow et al., in press). Thus, property rights holders govern the use of fish stocks within the legal limits defined by fisheries regulations. Furthermore, they decide and contract on recreational fisheries management, and can thus be defined as agents of the governance structure (Williamson 2002). Currently, angling clubs and angler associations are the dominant leaseholders of inland fishing rights for German freshwater ecosystems (Arlinghaus et al. 2002) and constitute common property rights regimes on fish resources (Daedlow et al., in press). The management boards of clubs or associations are therefore major agents of recreational fisheries governance in Germany. As mentioned above, the governance structure of recreational fisheries varies between East and West Germany because of a different institutional and cultural background before 1989 (Mau and Müller 1998, DAV 2004). During 40 years of separate historical developments, the East Germans constituted a group of recreational fisheries managers who were accustomed to topdown decision making in terms of operational management practices over large geographical areas. By contrast, West German recreational fisheries governance was locally organized in small angling clubs while West German angler associations mainly fulfilled representative, lobbying, and information tasks. We assumed that the different historical backgrounds of East and West Germans in recreational fisheries governance would play a major role in our attempt to delineate the adaptive cycle based on the connectedness and potential dimensions in East German recreational fisheries governance after the socio-political disturbance in 1989.

\section{LITERATURE REVIEW AND THEORETICAL BACKGROUND}

The very general properties of the adaptive cycle shaped by the distinct levels of the two dimensions, i.e., potential and connectedness, are supposed to provide a framework for assessing and describing adaptive change in ecological, social, and coupled SES (Holling and Gunderson 2002). A few studies stressed that some systems do not necessarily follow the adaptive cycle (Cumming and Collier 2005, 
Walker and Lawson 2006, Bunce et al. 2009). Most studies, however, have generally found the adaptive cycle heuristic to be useful for explaining changes in SES (Brunk 2002, Alcorn et al. 2003, Cocks 2003, Seixas and Berkes 2003, Abel et al. 2006). Most of these studies were explaining specific cycle phases such as the reorganization phase. However, some studies described and quantified the whole adaptive cycle in a SES. From a methodological point of view, most available studies used retrospectively qualitative reasoning (Peterson 2000, Bohensky 2008, González et al. 2008), or ecological, e.g., nutrient supply, and/or socioeconomic variables, e.g., timber harvest rates (Allison and Hobbs 2004, Beier et al. 2009), as well as dynamic models (Carpenter et al. 2001, Cumming and Collier 2005) to describe the adaptive cycle in SES. These studies thus exhibit a variety in methodological and analytical approaches and theoretical foundations while focusing on describing change in SES. Studies on adaptive cycles in social systems rather than SES are rare, however, and to our knowledge no research has attempted to quantitatively operationalize the different levels of the connectedness and potential dimensions as descriptors of particular phase transitions in a social system.

Two studies have explicitly focused on the two dimensions of connectedness and potential within an adaptive cycle when studying change in social systems. In the first study, Nkhata et al. (2008) provided a conceptual framework to represent the distinct phases of an adaptive cycle by analyzing long-term social relationships. They distinguished the connectedness and potential dimensions by considering trust and commitment as the two key attributes of the potential dimension, with trust referring to a state in which a party in a relationship adopts a belief that the other parties will not act against its interests (Luo 2002), and commitment referring to the energies and resources bonded by parties in long-term relationships (Ford et al. 1998). Similar to Holling and Gunderson (2002), the second dimension, i.e., connectedness, was defined by Nkhata et al. (2008) as the degree to which actors in social relationships are linked and the degree to which the strength of these links mediate change in social relationships. Based on a literature review, Nkhata et al. (2008) stressed the importance of both dimensions for facilitating the understanding of resilient social relationships. Their study revealed important concepts that should be included in quantitative analyses of phase shifts in social systems. In the second study, Abel et al. (2006) emphasized that "connectedness, e.g. in social networks, can imply the potential to, e.g. manage common property resources" (Abel et al. 2006:17), but both connectedness and potential in social systems can fall under the same category "capital." They also defined various subcategories such as social, human, natural, physical, and financial capital and assessed different levels of these subcategories of capital based on interpretations of case studies in regional SES in Zimbabwe and Australia (Fig. 6 in Abel et al. 2006). When applying their framework to the case studies, Abel et al. (2006) were unable to identify the sequential passages of the phases that the adaptive cycle heuristic implies and concluded that greater inclusion of disciplinary social science theories is needed to describe transitions between various system stages in social systems. These studies indicate that applications of the adaptive cycle to social systems are limited, and it has remained a challenge to measure the dimensions of the adaptive cycle in social systems (Carpenter et al. 2001, Gunderson et al. 2002) and to assess similarities and differences of this cycle in SES and social systems (Westley et al. 2002, Davidson 2010).

In general, studies on social, ecological, and/or coupled SES acknowledged the key role that social groups, actors, and institutions play in explaining social system behavior and change (Westley 1995, Berkes and Folke 1998, Adger et al. 2002, Gunderson and Holling 2002, Westley et al. 2002, Lebel et al. 2006, Walker et al. 2006, Janssen et al. 2007). Research frameworks that incorporate social groups, actors, and institutions have been developed to understand dynamics in social systems when dealing with natural resource management issues (Anderies et al. 2004, Folke et al. 2005, Olsson et al. 2006, 2008, Biggs et al. 2010, Chapin et al. 2010). Folke et al. (2005), for example, highlighted the social sources of adaptation in SES and emphasized that actors draw on various knowledge systems and experiences for the development of a common understanding and policies. The interplay of actors and institutions is seen as central in transitions and transformations of SES (Olsson et al. 2006, 2008). In this context, the role of social groups in policy decision processes and their outcome for ecosystem management have been highlighted (Chapin et al. 2010) and decision making by humans is generally seen to be rooted in previous cultural experience and customary institutional environments (Smit and Wandel 2006). Furthermore, Holling and Gunderson (2002:49-50) pointed to the likely 
importance of different social groups in a social system going through an adaptive cycle by including terms like "inside processes," "outside world," "among people," and "between people" in their definitions of connectedness and potential. However, to our knowledge, the influence of systematic differences among social groups based on distinct cultural and institutional backgrounds, such as possibly existing between East and West German recreational fisheries managers, has not been explicitly investigated in adaptive cycles or resilience studies. Thus, we extended our analytical approach to include intergroup relation theory when studying phase shifts in adaptive governance cycles.

Intergroup relation theory is a research field that investigates social group behavior while assuming systematic differences between distinct social groups that reflect group-based goals and orientations (Tajfel 1982, Fischer et al. 2007, Dovidio et al. 2009). Culture and identity are assumed to have major explanatory power in intergroup processes among different groups. Culture includes history, language, religion, preferences, beliefs, and attitudes. People who share a common history, language, or religion share the same identity and are members of the same group, usually defined as in-group (Worchel 2005). Consequently, a group of people who do not share this cultural background and who experienced different shared histories and customs form another belief system that can be defined as out-group (Worchel 2005). Tajfel and Turner (1979) argued that the social identity of individuals is partly based on the groups to which they belong and that individuals tend to provide advantages to their own group and discriminate against the out-group. Social identity studies revealed that East and West Germans can be treated as distinct social groups based on their socialization that occurred in completely different socioeconomic systems (Fuchs-Schündeln and Schündeln 2005, Kessler and Hollbach 2005, Alesina and Fuchs-Schündeln 2007, Fischer et al. 2007). These findings point to the importance of intergroup relations for human decision making in social systems in general, and for studies of policy decision processes involving East and West Germans in particular. Thus, in our analytical design, we assessed the progression of four phases of an adaptive cycle, based on connectedness and potential, and considered that the two governance alternatives in East and West Germany existing before 1990 represented distinct social groups with their own identities and customs in recreational fisheries resource governance.

\section{METHODS AND MATERIAL}

Our analysis of potential changes in East German recreational fisheries governance as an adaptive cycle was confined to the two dimensions potential and connectedness. The adaptive cycle heuristic includes the third dimension resilience (Holling and Gunderson 2002). The resilience dimension, defined as the capacity of the whole system to absorb disturbances and still maintain its ongoing functions and controls, captures system properties rather than explaining change as do the potential and connectedness dimensions (Holling and Gunderson 2002). Focusing on the potential and connectedness dimensions enabled us to sufficiently characterize the different phases of change in a potential adaptive cycle in East German recreational fisheries governance after the fall of the Berlin Wall in 1989. To be able to test the predicted levels of potential and connectedness in particular phases of the adaptive cycle (Fig. 1), we followed closely the definitions given by Holling and Gunderson (2002) and conceptualized both dimensions similar to Nkhata et al. (2008). Accordingly, we defined the connectedness dimension as the degree to which East German recreational fisheries managers were able both to control the processes in their management system and the corresponding angler community, i.e., internal connections, and to control for the influences from potential alternatives such as the West German governance approach, i.e., external variability. The potential dimension was defined as the value of connections within and between social groups by assessing the level of trust, respect, and/or friendship expressed by East German recreational fisheries managers toward their own community and toward the West German recreational fisheries community. We considered the effects of intergroup relations (Tajfel 1982, Worchel 2005, Dovidio et al. 2009) within and among different social groups in our analysis as ingroup, i.e., internal connectedness and potential within the group of East-Germans, and out-group dimensions, i.e., external connectedness and potential toward the group of West-Germans.

To assess all four dimensions, i.e., connectedness, potential, in-group, and out-group, we applied a novel approach using quantitative data from content analysis of articles in an angling magazine published by the East German umbrella angler association. These articles were assumed to be indicative of the values and opinions of leading managers in East German recreational fisheries governance during the transition process around 
1990. The monthly issues of the magazine were, and are, used by the leaders of the East German recreational fishing community to inform their members about recreational fisheries topics, including matters regarding organization, policy, regulations, and management. The managers, as the main stakeholders in the historical transition process, were, among other stakeholders, in charge of making decisions about the potential change or persistence of East German central recreational fisheries governance during and after the reunification. As authors of many of the articles in the angling magazine, the managers also expressed their perceptions about advantages and disadvantages of a potential transformation in the light of the West German governance alternative. Being aware that publication delay may have caused a time lag compared to the actual occasion of the underlying discussion, the articles provided adequate information about the current affairs in the decision making process in East Germany.

The traditional name of the East German angling magazine was Deutscher Angelsport (German Sport Angling). From October 1989 to April 1990 its publication was discontinued because of the revolutionary events in East Germany. From May 1990 onward, the magazine was published as a supplement in several angling magazines (Fisch und Fang until August 1991; Rute und Rolle until December 1996; Esox until December 2008; and since January 2009 in Blinker) and was renamed Angeln und Fischen (Angling and Fishing) in 1997. We evaluated the content of 25 cover articles from May 1990 to November 1994 (four in 1990, four in 1991, nine in 1992, five in 1993, and three in 1994) because the major discussion regarding the reorganization of recreational fisheries governance took place during that time period. From 1994 onward, the topic only appeared occasionally to substantiate the policy choice made in the early 1990s (one in 1995, three in 1996, four in 1997, one in 2000, and one in 2003). The choice to focus the analysis on cover articles rested on their prominent position to inform the readers of the magazine, assuming that the most important issues are positioned on the first page.

We used content analysis to evaluate the cover articles (Früh 2007). We developed a coding scheme representing four facets of analytical importance: the potential and connectedness dimensions and the in-group and out-group dimensions (Table 1). In our case, the in-group dimension represented positive statements by East German managers about their own central governance approach as well as negative or critical perceptions toward West German managers and their local governance approach, which in turn indirectly emphasized positive statements about their own peer group and governance approach. The out-group dimension represented positive perceptions of East German managers toward the West German managers and their local governance approach and included negative perceptions about their own customary central system. In all codes, in-group and out-group were always connected to the dimensions connectedness and potential. The connectedness and potential dimensions were measured separately (Table 1). Similar to the definition of Holling and Gunderson (2002:50) and Nkhata et al. (2008), Pretty and Ward (2001) defined connectedness in social systems as different types of connections among groups and organizational levels; it is regarded as linkages developed for reciprocity and exchange processes within or among groups such as exchange of information, common meetings and celebrations, or trading of goods. Connectedness can also help to increase trust and friendship among groups or individuals (Pretty and Ward 2001). However, the causality between connectedness and trust is sometimes unclear (Rowley 1999). Trust, friendship, and respect are, by contrast, fundamental elements of Holling and Gunderson's (2002) definition of potential. Trust can be defined "as the belief that others will not deliberately or knowingly do us harm, if they can avoid it, and will look after our interests, if this is possible" (Newton 2007:343). It represents the value of a relationship, not the intensity of its connections. We followed this description and terminology when defining potential in our case study. In addition to trust, friendship, and respect, we also considered perceived skills of group members as an indicator of potential (Holling and Gunderson 2002).

We developed five subcategories to measure the potential dimension: abilities, group support, trust, respect, and friendship (Table 1). These different subcategories showed the perceived value of the relationship within the group of East German managers, i.e., in-group, and their relationship to West German management, i.e., out-group. For example, the abilities of East German recreational fisheries managers were emphasized in an article in April 1991: "There is no reason to discard all skills, which were developed in the former GDR even though this state does not exist anymore" (Schwandt 
Table 1. Coding scheme for the evaluation of the cover articles: five subcategories for the connectedness and the potential dimension (number of coded statements in brackets) were developed. Examples of identified statements for each subcategory and in-group and out-group dimensions are provided. Note: DAV = Deutscher Anglerverband, the East German umbrella association for anglers; VDSF = Verband Deutscher Sportfischer, the Association of German Sport Fisheries in the West.

\begin{tabular}{|c|c|c|}
\hline $\begin{array}{l}\text { Dimensions and } \\
\text { subcategories }\end{array}$ & $\begin{array}{c}\text { Examples of statements supporting } \\
\text { in-group (East) }\end{array}$ & $\begin{array}{l}\text { Examples of statements supporting } \\
\text { out-group (East towards West) }\end{array}$ \\
\hline \multicolumn{3}{|l|}{ Connectedness: } \\
\hline $\begin{array}{l}\text { Organization } \\
\text { (28 statements) }\end{array}$ & $\begin{array}{l}\text { "The simultaneous membership in DAV and } \\
\text { VDSF is not possible" (Apr 1992) }\end{array}$ & $\begin{array}{l}\text { "Cooperation between DAV and VDSF } \\
\text { develops well" (Jun 1990) }\end{array}$ \\
\hline $\begin{array}{l}\text { Control } \\
\text { (8 statements) }\end{array}$ & $\begin{array}{l}\text { "Protection of the achievements of the DAV" } \\
\text { (Apr 1991) }\end{array}$ & No code assigned \\
\hline $\begin{array}{l}\text { Self-conception } \\
\text { ( } 55 \text { statements) }\end{array}$ & $\begin{array}{l}\text { "We - the DAV provide a home for all anglers" } \\
\text { (Jan 1993, Apr 1992) }\end{array}$ & No code assigned \\
\hline $\begin{array}{l}\text { Meetings } \\
\text { (42 statements) }\end{array}$ & $\begin{array}{l}\text { "Suggestions for cooperation were not } \\
\text { answered" (Oct 1992) }\end{array}$ & $\begin{array}{l}\text { "Four working groups are going to meet every } \\
\text { three month" (Jun 1990) }\end{array}$ \\
\hline $\begin{array}{l}\text { Unification } \\
\text { (31 statements) }\end{array}$ & $\begin{array}{l}\text { "VDSF is not interested in an equal and } \\
\text { proportional unification" (Sep 1992) }\end{array}$ & $\begin{array}{l}\text { "On the way to an unified umbrella } \\
\text { organization" (Dec 1990) }\end{array}$ \\
\hline \multicolumn{3}{|l|}{ Potential: } \\
\hline $\begin{array}{l}\text { Abilities } \\
\text { (8 statements) }\end{array}$ & $\begin{array}{l}\text { "There is no reason to discard all skills, which } \\
\text { were developed in the former GDR even though } \\
\text { this state does not exist anymore" (Apr 1991) }\end{array}$ & $\begin{array}{l}\text { "The VDSF will not blind itself when help and } \\
\text { advice is needed" (Dec 1990) }\end{array}$ \\
\hline $\begin{array}{l}\text { Group support } \\
\text { (3 statements) }\end{array}$ & $\begin{array}{l}\text { "Association meeting was a clear and } \\
\text { convincing vote for the continued existence and } \\
\text { legal capacity to act" (Apr 1991) }\end{array}$ & $\begin{array}{l}\text { "Despite different starting points a common } \\
\text { understanding was created very fast" (Jun } \\
\text { 1990) }\end{array}$ \\
\hline $\begin{array}{l}\text { Trust } \\
\text { (24 statements) }\end{array}$ & $\begin{array}{l}\text { "VDSF defamed DAV board members in } \\
\text { public" (Aug 1992) }\end{array}$ & "Further trustworthy cooperation" (Dec 1990) \\
\hline $\begin{array}{l}\text { Respect } \\
\text { (52 statements) }\end{array}$ & $\begin{array}{l}\text { "We do not have fears about contact but we } \\
\text { must be treated fair" (Aug 1992) }\end{array}$ & $\begin{array}{l}\text { "Convergence without fears about contact" } \\
\text { (Feb 1990) }\end{array}$ \\
\hline $\begin{array}{l}\text { Friendship } \\
\text { (12 statements) }\end{array}$ & $\begin{array}{l}\text { "We do not have any hopes for a partnership } \\
\text { with the VDSF" } \\
\text { (Aug 1992) }\end{array}$ & $\begin{array}{l}\text { "Consultations in very jovial atmosphere" (Jun } \\
\text { 1990) }\end{array}$ \\
\hline
\end{tabular}

1991:1, our translation). An example of out-group support was provided, by Deutscher Anglerverband (DAV), the East German umbrella association for anglers, of an East German manager valuing the relationship between East and West Germans as follows: "Despite different starting points, a common understanding was created very fast" (DAV 1990:1, our translation). An example of losing trust between DAV in the East and their West German equivalent, Verband Deutscher Sportfischer (VDSF) was, "VDSF defamed DAV board members in public" (Mikulin 1992:1, our translation), which indicated that verbal insults between both groups took place. We coded this statement under the in-group category because it had a negative connotation toward the West German 
managers and likely unified the East German group. A high frequency of statements about potential indicated the importance of certain relationships either within or between the two groups of East and West Germans.

To measure connectedness we developed five subcategories: organization, control, self-conception, meetings, and unification (Table 1). The subcategory 'organization' measured the level of control over group joining, i.e., being a member in either one or both of the East and West German groups. Statements were similar in the subcategory 'unification' in which East German managers expressed their opinion about a potential connection or union with the West German angler association. Under the subcategory 'meetings' we coded statements about actual or envisaged meetings between the groups or the refusal of meetings from one or the other group. With the subcategory 'selfconception' we aimed to capture statements that stressed common issues in fisheries governance either within one group or between groups. For example: "We - the DAV provides a home for all anglers" (DAV 1992:1, our translation), showing support for the East German angler association (Table 1). With 'control' we measured statements that indicated the achievements of a certain governance approach and were worth continuing. The frequency of statements about connectedness to one or the other group was assumed to indicate how rigid (high frequency) or loose (low frequency) the control of internal or external processes was.

Coding of statements was completed by two independent coders. When agreement could not be found, codes were excluded from the analysis (11\% of all assigned codes). The data analysis included 263 coded statements. The codes were assigned to each paragraph (coding unit), with each paragraph being treated as a single unit of information. This was considered appropriate because treating sentences or even words as the basic unit of information breaks information into many small pieces and does not necessarily provide the full suite of meaning with respect to the writer's perceptions or opinions (Gläser and Laudel 2004, Früh 2007). Note that the examples of statements given in Table 1 to illustrate the subcategories are half sentences or sentences because they serve as anchors for the primary information coded in the particular paragraph. After the coding of the first five articles, the exploratively assigned codes were compared and discussed between the two coders. An adjustment of the four main dimensions and their subcategories was not deemed necessary at this point. The average total intercoder reliability $(0.76)$ was estimated following Holsti (1969) and ranged between 0.71 and 0.81 for the four dimensions (ingroup connectedness: 0.81 ; in-group potential: 0.81; out-group connectedness: 0.71 ; out-group potential: 0.72 ). The calculation of the intercoder reliability was based on the precondition that the codes referred to a specific paragraph in the text (our coding unit), not to the entire article (Früh 2007).

After the completion of the coding process, all codes assigned to a paragraph were summarized on a per article basis that was defined as the unit of analysis, according to the four dimensions of the coding scheme. We decided not to subdivide the analysis regarding individual subcategories such as 'friendship,' 'trust,' etc., because the distribution of the subcategories within the connectedness and potential dimensions did not influence the results. In addition, for two subcategories no statements were coded ('control' and 'self-conception' for outgroup, see Table 1). Thus, we analyzed data in pools related to the two dimensions, potential and connectedness, and further partitioned into the ingroup and out-group dimensions. To compare trends over time, we calculated the relative frequency of coded statements per dimension and article. After the calculation of the relative frequency of coded statements, we first looked for trends in the relative frequency of potential and connectedness statements over time. To test for temporal patterns, we first plotted the time series of the relative frequency of connectedness and potential statements with the in-group and outgroup information pooled. This was done because the adaptive cycle heuristic does not distinguish between in-group and out-group (Fig. 2). In a second step, we plotted connectedness and potential separately for the in-group and out-group dimensions (Fig. 3). Finally, we pooled the connectedness and potential dimensions together and plotted only the relative frequency of in-group and out-group statements separately (Fig. 4). Only in the last step of the analysis we were able to identify the four phases of the adaptive cycle. To help in understanding and interpreting our results, we added the four phases of an adaptive cycle identified in this last step to all figures in the results (Figs. 2 and 3).

As a supplementary data source, we also conducted 10 semistructured, in-depth interviews with 
Fig. 2. Predicted levels of potential and connectedness in the adaptive cycle (panel a, Holling and Gunderson 2002) and the levels of potential and connectedness assessed as relative frequencies of connectedness and potential statements in our case study (panel b). Phases shown are derived from Fig. 4 and serve for illustrative purpose.

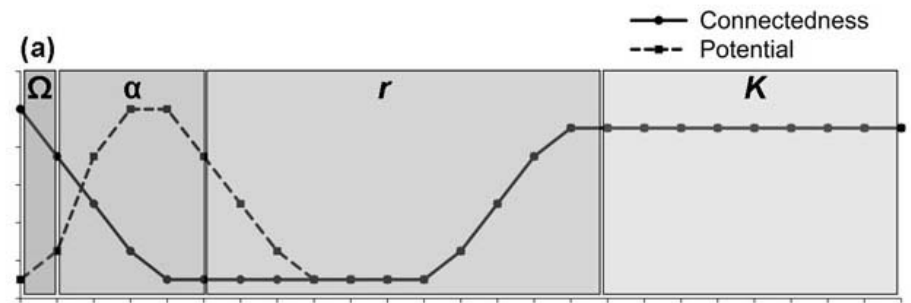

(b)

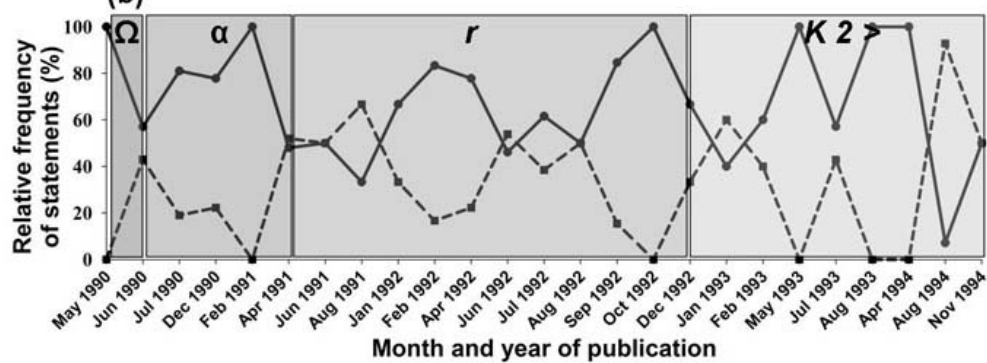

contemporary recreational fisheries managers to obtain insights into the historical sequences of decision making during the transition process in recreational fisheries governance after the fall of the Berlin Wall. Almost all interviewees were key members of East German recreational fisheries associations on the national or district level and were responsible for resource management and decision making during the transition process. The semistructured, open questionnaire used for the interviews was divided into three parts that covered the following subject areas: (1) recreational fisheries governance in the former GDR, (2) decision making during and after the reunification, and (3) recreational fisheries governance in East Germany today. Historical facts were similarly described by all interviewees. Based on these data, we collected qualitative information about adaptation and persistence in the governance structure and about the actual sequence of the transition process, e.g., when the decision for adapted central governance in large parts of East Germany took place. We structured and headlined the system narrative based on the information given in the interviews according to phases and key attributes of the adaptive cycle heuristic. Providing the qualitative information first facilitates the understanding of the patterns visible in the quantitative analysis of the magazine articles.

\section{RESULTS}

\section{System origin and growth of internal connections: connectedness}

After the Second World War, in 1949, the new GDR state was founded on East German territory. The central socialist government broke with the tradition of recreational fishing rights tenures by local angling clubs that existed prior to the end of the Second World War. In the 1960s, the GDR established a central fisheries management system with a nation-wide fishery law for inland waters regulating recreational and commercial fishing rights, fish production, and fish resource use such as size-based harvest limits and closed seasons. Recreational fisheries management was mainly organized by the national angler association, called "DAV of the GDR" (Deutscher Anglerverband der DDR), which was founded in 1954 (Winkel 1998, DAV 2004). The DAV played a paramount role in recreational fisheries governance and management, and fisheries authorities focused on commercial fisheries. The DAV, authorized by the national government to use and manage all recreational fisheries, was responsible for the planning and execution of local and regional management measures such as fish stocking or determination of 
Fig. 3. Relative frequency of connectedness and potential statements separated by in-group and outgroup dimensions. Phases shown are derived from Fig. 4 and serve for illustrative purpose.

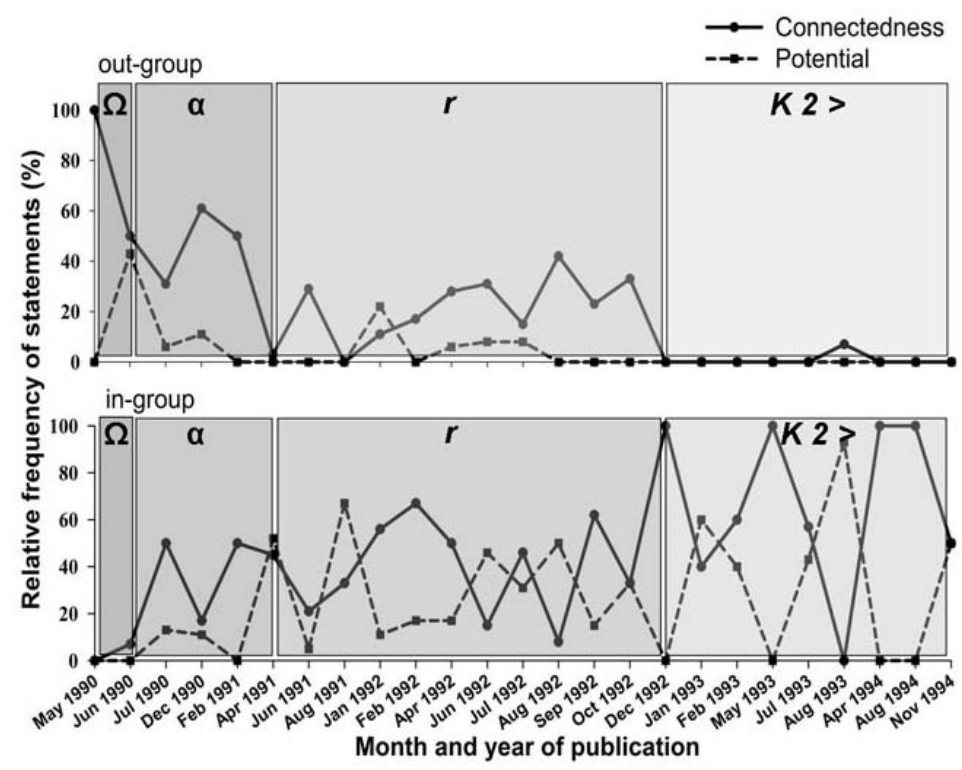

access and use regulations. The umbrella association in the capital Berlin appointed all recreational fisheries managers on the district or county level. Associations on the district or county level in collaboration with the angling clubs on local levels supported the umbrella association inter alia in terms of fish stocking measures, guarding of waters, anglers' education, monitoring of fish resources, and anglers' behavior. Thus, the DAV angler association controlled the entire system and mediated and influenced decision making for recreational fisheries management.

\section{Accumulation of internal system resources: potential}

From the recreational fisheries managers' perspective, fisheries governance in the GDR was generally well functioning under the conditions of a planned economy (Winkel 1998, DAV 2004). Angler desires were thought to be generally satisfied because of exceptionally low fees for membership and fishing permits, and the easy access to angler association waters nationwide. The number of fishing permits for nonpredatory fish was not restricted by the DAV or fisheries authorities. The
DAV also ran several fish production facilities to produce fish for stocking programs. The recreational fisheries management system in the GDR highly depended on voluntary work, but the people in charge had several benefits from voluntary engagement, e.g., days off from work, and the managers' work was highly appreciated by society. For instance, stocking programs and recreational fisheries in general were considered important by political decision makers because they assisted fish supply in the GDR, provided valuable forms of recreation, and facilitated social cohesion and social capital. Management problems arose from a number of external factors, for example, from supply limitations for angling tackle and other technical equipment, from limited access to production facilities for desired fish species other than the abundantly available carp (Cyprinus carpio L.) for stocking programs, or from industrial pollution that endangered fish stocks in rivers and lakes. Nonetheless, based on mutual experiences and work relationships, it was perceived by the interviewees that recreational fisheries governance developed into a generally well-functioning $K$ state after the implementation of a centrally planned economy in the GDR, with notably high internal potential and connectedness levels. 
Fig. 4. Relative frequency of in-group and out-group statements showing the phases of an adaptive cycle.

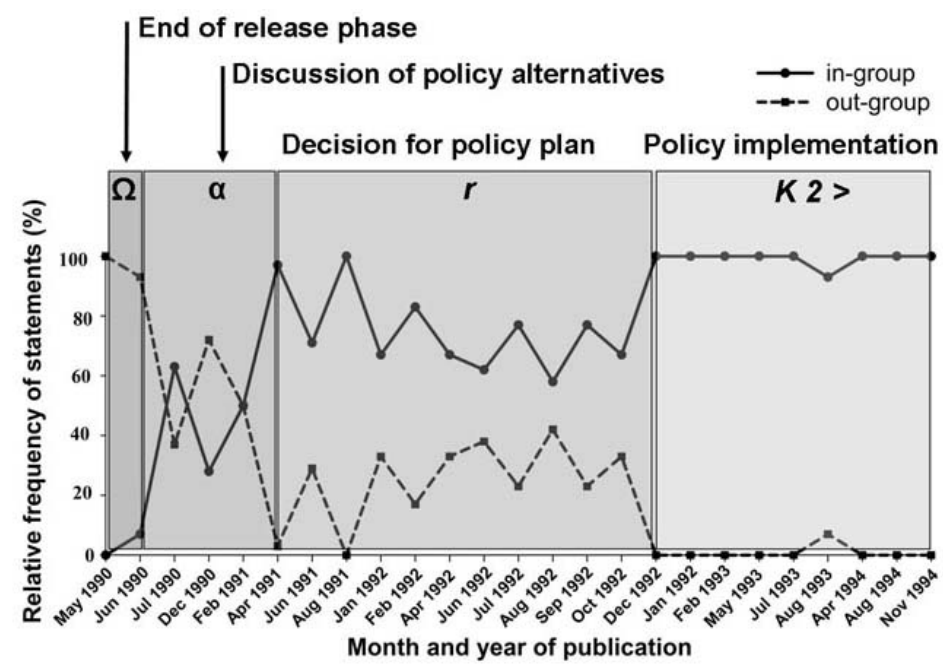

The governance alternative in West Germany: external variability in the background

The governance alternative of West German recreational fisheries was, and is characterized by a decentralized governance approach in which local angling clubs rather than umbrella angler associations own or lease fishing rights (Arlinghaus et al. 2002, Arlinghaus 2006). Since about 125 years ago, recreational fishers started to lease or buy fishing rights for local lakes and rivers from water owners such as state authorities or counties (Haase 2000). This historically emergent governance approach continued to exist in West Germany after the Second World War. The duties and rights of resource management, particularly regarding the planning and execution of fish stocking measures and the implementation of specific access and use regulations, e.g., size-based harvest limits, were usually held by angling clubs at the local level as long as they were in line with the minimum standards set by the state-specific fisheries legislation. This can create comparatively expensive and restrictive memberships in angling clubs in areas with high population density where competition for scarce waters held by angling clubs is high. Moreover, angling activity on other waters from neighboring angling clubs requires new membership and angling permits. This small-scale governance approach, which was and is still functional today in West Germany, has advantages because of local monitoring of water bodies and local accountability to fisheries management (Daedlow et al., in press). Any contact or cooperation between East German and West German recreational fisheries managers before 1989 was forbidden by the GDR.

\section{Externally induced disturbance in 1989 and system reorganization}

The rapid reunification process that started in 1989 was a heavy disturbance and externally motivated "surprise" for the East German recreational fisheries community that initiated a release phase $(\Omega)$ from the $K$ state. A need for a major change in recreational fisheries governance was not originally perceived in the East German angling community and among its managers. In this emerging window of opportunity, discussions about potential improvements to the customary governance approach started on local, regional, and national levels, such as the question whether small angling clubs rather than large associations should become owners or leaseholders of fishing rights similar to West Germany. Some East German recreational fisheries managers and anglers seriously considered implementing this alternative during the $\alpha$ phase after the fall of the Berlin Wall in November 1989 
to replace the more centralized approach to recreational fisheries governance of the GDR. In addition, West German civil servants, who were used to local level fisheries governance, were delegated to support the East German fishery administration and stakeholders in the formulation and implementation of new fishery laws and administrative regulations. With the fast change of the political and economic system, the East German recreational fisheries managers were forced to rapidly adapt to the newly implemented West German Civil Law Code. However, the majority of managers argued against the local governance approach questioning the success of inexperienced angling clubs in East Germany. This suggested a lack of out-group potential and a lack of belief in the skills and experience of local angling clubs to manage fisheries independently of a large umbrella angler association. Furthermore, numerous East German anglers on the local level were highly insecure about future developments, and tended to welcome customary decision making by regional and national managers, suggesting high in-group potential and connectedness. The historical changes and policy decision processes were under enormous time pressure and were perceived as highly challenging for East German recreational fisheries policy makers and managers because of their unknown character. This caused transaction costs in terms of time, money, and learning as evidenced by all contemporary witnesses.

\section{Persistence of central governance characteristics after 1989}

At a major angler association meeting held in February 1991 in Pätz with representatives from all states in East Germany, the East German recreational fisheries managers decided to maintain the customary central governance approach developed in the former GDR (DAV 2004). This date marked the decision for a policy plan $(r)$ and the legally required adaptations were executed, e.g., the subrogation of fisheries sovereignty from the federal to the state level. Elections were held in clubs and associations to assign managers in charge, and fishing rights were re-leased to the newly founded state angler associations, which replaced the national umbrella association as former management decision maker. In general, East German managers opted against the implementation of the West German governance alternative. In terms of the adaptive cycle heuristic, an option for the West German approach would have meant a system transformation moving fisheries governance into a new configuration. Instead, the similar pattern in structure and function indicates the resilience of recreational fisheries governance in East Germany. However, one can now also find some independently organized angling clubs with their own fishing rights, in particular in southern parts of East Germany. Today, two independent umbrella angler associations exist on the national level in Germany representing the different governance approaches for recreational fisheries between East and West, the DAV in the East and the Association of German Sport Fisheries (VDSF) in the West, with associated members in both parts of Germany. Overall, the East German recreational fisheries governance system exhibited a high degree of institutional persistence (K. Daedlow, V. Beckmann, M. Schlüter, and R. Arlinghaus, unpublished data).

\section{Content analysis of cover articles}

To test for the sequences of the four phases of an adaptive cycle along with their time frames, we quantitatively evaluated the two dimensions, potential and connectedness, together with the ingroup and out-group dimensions by using content analysis of magazine articles published by the East German angler association. The results of the first step of our content analysis, i.e., time series of pooled connectedness and potential statements, did not show any obvious pattern (Fig. 2b). Thus, the time series trends for connectedness and potential did not support the assumptions derived from the adaptive cycle heuristic (Fig. 2a). For example, in the $\alpha$ phase, potential should be high and connectedness low, but this was not visible in the pooled relative frequencies of the potential and connectedness dimensions. When we then looked at connectedness and potential statements separately for the in-group and out-group (Fig. 3), we were able to see one trend over the whole time period: the codes assigned to the connectedness and potential dimensions in the out-group category were decreasing from the $\Omega$ to the $K 2$ phase (Fig. 3, top panel), whereas the codes assigned to the connectedness and potential dimensions in the ingroup category were increasing (Fig. 3, bottom panel). Although we were able to identify these distinctive trends of increasing in-group and decreasing out-group statements (Fig. 3), we were still unable to completely trace the theoretically 
assumed combinations of low and high levels of connectedness and potential as predicted in the adaptive cycle heuristic (Table 2). Aside from the dominance of connectedness over potential statements regardless of the in-group and out-group dimensions, we ascertained three main differences from theoretical assumptions. First, the release phase $(\Omega)$ showed both a low degree of connectedness and potential in the social group, which had to face the change (in-group), and a high degree of connectedness and potential toward a social group, which offered an alternative in recreational fisheries governance (out-group). Second, in the reorganization phase $(\alpha)$ we saw in both the in-group and out-group dimension a high frequency of connectedness statements, which were inversely related to the prediction of the adaptive cycle heuristic (Table 2). Third, the assumed low frequency of connectedness and potential in the exploitation phase $(r)$ could only be affirmed for the out-group category, whereas in the in-group category connectedness and potential were already high. The same pattern occurred in the $K 1$ and $K 2$ phases (Table 2). In summary, the level of in-group and out-group connectedness and potential varied substantially over time with no obvious pattern clearly demarcating the four phases of an adaptive cycle.

The four phases of an adaptive cycle emerged clearly once we grouped connectedness and potential dimensions together and plotted the trend only with the relative frequencies of in-group and out-group statements from the pooled data (Fig. 4). The first two articles (May and June 1990) contained a high frequency of supporting statements regarding the West German (out-group) governance alternative (Fig. 4). Taking the externally induced disturbance as an opportunity for change, articles in both May and June 1990 pointed to a critical rethinking of the customary central governance approach by the East German anglers' community in the $\Omega$ phase. A phase of discussion about the two policy alternatives ( $\alpha$ phase) started, indicated by marked up and downs of the in-group and out-group statements in the three cover articles from July 1990, December 1990, and February 1991 (Fig. 4). The discussion halted in April 1991 when in-group statements started to dominate all articles. This dominance continued until November 1994 (Fig. 4). In the article from April 1991, the board of the national umbrella association declared the maintenance of the central governance approach at the state and regional level in East German recreational fisheries (Schwandt 1991) after the decision was made at the extraordinary association meeting in February 1991 (start of policy plan phase $r$ ). Some out-group statements were still expressed until October 1992. Growing self-confidence was represented by high in-group frequencies of connectedness and potential during the $r$ phase (Fig. 4), which stabilized on a high level from December 1992 onward (K2 phase). Thereafter, out-group statements almost completely disappeared. This was a clear signal of in-group identity and the perceived superiority of one's own customary governance approach. In summary, the distinct examination of the in-group and out-group dimensions revealed the strongest patterns in the results regarding the demarcation and development of the different phases of the adaptive cycle in the East German recreational fisheries governance system (Fig. 4).

\section{The time frames of the four phases synthesized from interviews and cover articles}

Our findings from the content analysis of cover articles in conjunction with the narrative of the transition process can be stylized as the four phases of an adaptive cycle of East German recreational fisheries governance after 1989 (Fig. 4, Table 3). The $K 1$ phase represented the central governance approach in East Germany, which was implemented from the early 1950s onward and worked sufficiently for 35 years until the start of the transition process in 1989. The beginning of the $\Omega$ phase could be traced to the discontinuation of the publication of the East German anglers' magazine from October 1989 to April 1990. The public discussion about the future of East German recreational fisheries governance started with the publication of the first magazine issue in May 1990. Accordingly, the $\Omega$ phase of the adaptive cycle was estimated to have taken about nine month from October 1989 to June 1990. The $\alpha$ phase, which started around July 1990, lasted for about eight months. As assumed in the adaptive cycle heuristic, the $\Omega$ and $\alpha$ phases were faster than the others phases of the adaptive cycle. The $r$ phase continued for 1.5 years after the final policy plan was agreed upon in February 1991 and published in April 1991. The policy plan was implemented from December 1992 onward (K2). Thus, the full progression of adaptation from the end of the $K 1$ phase (October 1989 ) to the start of the $K 2$ (December 1992) lasted about three years. 
Table 2. Level of connectedness (C) and potential (P) as predicted by the adaptive cycle heuristic (Holling and Gunderson 2002) and assessed in our case study in total and for the in-group and out-group dimensions for each of the four phases. (+) indicates high level and (-) indicates low level of connectedness and potential

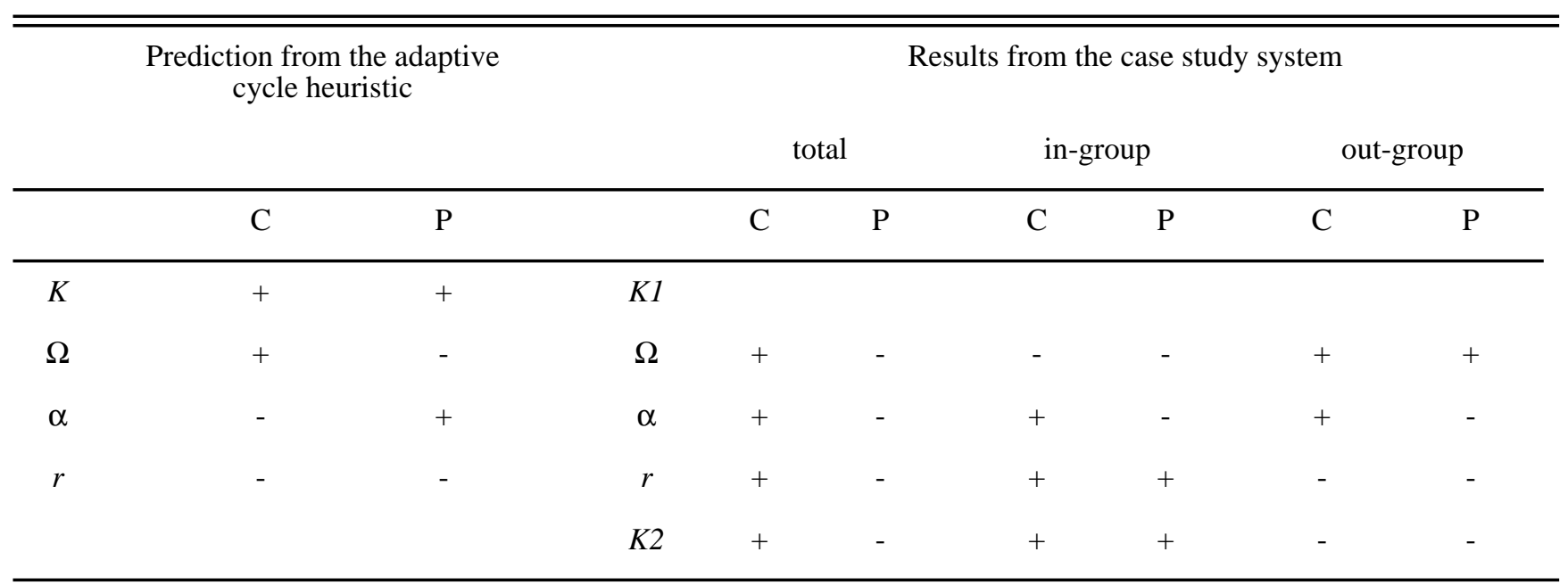

\section{DISCUSSION}

The objective of our study was to demarcate the four phases of an adaptive cycle in the East German recreational governance system after the fall of the Berlin Wall based on measures of connectedness and potential dimensions in historical cover articles (Figs. 2 and 3). We were unable to unambiguously delineate the "figure-eight model" of the adaptive cycle using our quantitative approach to predict the assumed combinations of high or low potential and connectedness dimensions (Table 2). However, we found that time series trends of in-group and outgroup statements, not distinguished into separate connectedness and potential dimensions, enabled us to navigate through the four phases of an adaptive cycle on a monthly basis (Fig. 4). The speed of phase shifts was found to confirm with the predictions of the adaptive cycle heuristic (Holling and Gunderson 2002). Our findings from the content analyses were supported by the narrative information about the transition process in East German recreational fisheries governance generated from in-depth interviews with contemporary witnesses (Table 3 ). A combination of analytical and methodological aspects help to explain this finding, as discussed below.

One reason for our assessed patterns of incongruity to the prediction from the adaptive cycle heuristic using quantitative connectedness and potential indicators alone (Table 2), might reside in the analytical challenge of identifying and unambiguously measuring indicators representing the degree of potential and connectedness in social systems because of their similarity to the overarching concept of social capital (Abel et al. 2006). Indeed, the subcategories we developed to assess the connectedness and potential dimensions (Table 1) by following the definitions by Holling and Gunderson (2002) and Nkhata et al. (2008), appear in the literature as varying conceptualizations of social capital such as relations of trust; reciprocity and exchanges; common rules, norms, and sanctions; and connectedness in networks and groups (Coleman 1988, Pretty 2003). The varying frequency of our assigned statements per subcategory to assess the connectedness and potential dimensions points to the difficulty of unambiguously distinguishing the two dimensions. Although all subcategories of connectedness codes were assigned with similar frequency (except control with only 8 statements), the codes to measure potential were mostly assigned to the subcategories 'respect' (52 statements), 'trust' (24 statements), and 'friendship' (12 statements). 'Abilities' (8 statements) and 'group support' (3 statements) were only sparsely assigned in the potential dimension. One reason for the low number of codes assigned to the subcategories 'abilities' and 
Table 3. The phases of the adaptive cycle exemplified by East German recreational fisheries governance over the course of 50 years.

K1 $\begin{aligned} & 1954-1989 \text { (35 years): Policy implementation and conservation of central recreational fisheries governance in the } \\ & \text { former GDR }\end{aligned}$
$\Omega \quad$ October 1989 - June 1990 (9 months): Disturbance \& policy release of the $K 1$ system
$\alpha \quad \begin{aligned} & \text { July } 1990 \text { - April } 1991 \text { ( } 8 \text { months): Opportunity of change for a new governance approach in East Germany in the } \\ & \text { reunification process, discussion of policy alternatives }\end{aligned}$
$r \quad$ April 1991 - October 1992 (18 months): choice of policy plan (pattern of persistence)
$K 2 \quad \begin{aligned} & \text { From December } 1992 \text { on: Implementation of the current governance approach in East Germany with high } \\ & \text { institutional persistence in comparison with the " } K l \text { " status }\end{aligned}$

'group support' within the potential dimension might lie in the challenge of separating them clearly from the 'self-conception' and 'control' subcategories of the connectedness dimension. In future studies, we therefore suggest focusing on the character of relationships such as trust, friendship, and respect to assess potential, and on strength of selfconception in organizational matters and meetings of networks and groups to assess connectedness.

Alternative explanations for our findings might be related to the particular characteristics of our case study. A reason for the low explanatory power of connectedness and potential in our analysis might lie in the exceptional situation of an externally induced disturbance to East German recreational fisheries rather than an internally induced motivation of agents of the governance structure to adapt their system. East German managers likely tried to avoid unintended changes in the governance transition process, which might be reflected by the high level of in-group connectedness revealed in our content analysis of cover articles (Table 2). This characteristic was supported by the fact that East German managers exhibited high capabilities for self-organization to deal with the socio-political and legal challenges in the comparatively minor policy field of recreational fisheries governance after the external and surprising "disturbance" of the German reunification. These people were empowered to largely control the reorganization of recreational fisheries governance and the majority of traditionally thinking, politically influential, and vocal East German managers likely impeded supporters of the West German governance alternative. These features might explain the low levels of out-group potential and high levels of ingroup connectedness we revealed in the analysis of cover articles (Table 2). The majority of East German fisheries managers seemed to have followed a "controlling strategy" (Holling and Gunderson 2002:52) for dealing with external variability, i.e., resources and knowledge from West Germany, to maintain the customary, centralized Eastern fisheries governance approach. These case characteristics altogether likely increased the clarity of the in-group and out-group dimensions helping to demarcate the four phases of an adaptive governance cycle.

Further limitations of our approach to assess the potential and connectedness dimensions can be traced to the methodology of a quantitative content analysis of newspaper articles. One source of error is the degree of subjectivity that was associated when assigning codes to coding units. We tackled this by using two coders. The average total intercoder reliability of 0.76 was generally high indicating a valid quantification approach (Früh 2007). Another limitation was that the cover articles constituted a single source of information reflecting mainly one perspective, i.e., the one from particular East German recreational fisheries managers in charge of policy decision making who were influential enough to become an author. It is likely that not every opinion was published. As a result of the data availability in monthly published magazines, a single author's opinion in a given year strongly influenced the time series trends in our study. However, the people expressing their 
opinions in the media were surely key players and in charge of implementing adaptations in East German recreational governance after 1989. Thus, their written material may be perceived as a suitable source for analyzing decision making dynamics in the East German recreational fisheries governance system. Furthermore, our coding system did not distinguish between information about the actual process taking place at a particular point in time and the intended strategies of actors influencing and directing the public discussion in a particular direction. We balanced this bias by conducting interviews, but using other written data sources was difficult because of the lack of information and access to historical documents. Other data indicative of the connectedness dimension such as actual number of meetings, network data analysis of key managers, etc., was thus impossible to generate in the face of the loss of most written documents after 20 years. Such data should be collected or stored when a given transition process is actually happening, as it will help to better assess and quantify the connectedness and potential dimensions in various phases of an adaptive cycle after a system's disturbance.

Facing the above mentioned limitations, the question arises whether an adaptive cycle in the spirit of Holling and Gunderson (2002) actually happened in East German recreational fisheries governance after 1989, because a lack of a cycle would also explain why we were unable to delineate it using connectedness and potential dimensions inferred from our quantitative analysis of cover articles. Based on the information from the interviews and our historical reconstruction of the case, we contend an adaptive cycle did occur in East German recreational fisheries governance in response to the socio-political disturbance caused by the German reunification (Fig. 4, Table 3). However, it is likely that our content analysis captured an underlying adaptive cycle representing shifting communication dynamics between ingroup and out-group relations among different preferences of social groups when negotiating policy changes. This may be interpreted as indicative of a nested "communicative adaptive cycle" within an overarching "governance adaptive cycle." Our data analyses thus may have been less representative of the actual transition and adaptation of the governance system as much as a function of a system's connectedness and potential dimensions.
The clarity of the in-group and out-group dimensions describing the four phases of adaptation in East German recreational fisheries governance (Fig. 4) emphasizes the importance of intergroup relations for social transition processes and for the understanding of reorganization and decision making prior to the choice of a policy plan. Other studies have also emphasized the essential role of people's preferences in policy-decision making processes in cases of implementation of new governance structures (Trosper 2003, Olsson et al. 2004, 2008). Our case study is an example for the persistence of customary governance structures based on managers' preferences after an externally motivated, severe, and rapid system disturbance. Regardless of the outcome of policy decisions in a transition process, i.e., transformation or adaptation of a governance system's characteristics, the general "importance to identify common social values among players of the new system and to empower key stakeholders to participate in decisions that legitimize relationships and interactions of the new regime" (Chapin et al. 2010:247) is acknowledged in frameworks to study transition processes and system's transformation or transition (Adger et al. 2002, Anderies et al. 2004, Folke et al. 2005, Lebel et al. 2006, Olsson et al. 2006, 2008, Walker et al. 2006, Janssen et al. 2007, Biggs et al. 2010, Chapin et al. 2010). Our case study in recreational fisheries governance confirms that identity, norms, and tradition of different social groups play a major role in governance adaptation processes.

Finally, in the context of the importance of studying transition processes in social systems where key actors have the opportunity to change or maintain governance structures in natural resource management (Olsson et al. 2008, Chapin et al. 2010), our empirical finding of high levels of connectedness in all four phases of the adaptive cycle of East German recreational fisheries governance (Table 2) is insightful. The high level of internal control (in-group connectedness) that the East German recreational fisheries managers exerted over external variability and alternative options might have constrained the development of shared abilities, trust, mutual respect, or friendship in intergroup relations with the West Germans (outgroup potential). Thus, despite our inability to demarcate the four phases of the adaptive cycle based on quantitatively measured connectedness and potential dimensions, it still seems valuable to 
distinguish between both dimensions in social systems because it gives insights into the ability of particular social groups to influence the policy decision process for preferred governance approaches (Olsson et al. 2008, Chapin et al. 2010). This idea corresponds with that of Nkhata et al. (2008) who highlighted the importance of both dimensions for analyzing long-term social relationships. Our result of high levels of connectedness in all phases despite disagreement with theoretical predictions of low connectedness levels in $\alpha$ and $r$ phases by Holling and Gunderson (2002) are likely explained by the ability of humans to consciously control the future shape of a SES, which is supposed to be a major difference from entirely self-organized processes in ecological systems (Gunderson et al. 2002, Westley et al. 2002).

\section{CONCLUSION}

Difficulties with empirically testing the adaptive cycle heuristic in social systems were stressed by Holling and Gunderson (2002) who emphasized that the very general properties of the adaptive cycle are supposed to help to develop frameworks for assessing adaptation and are rather more of a metaphor to interpret events and their causes than a fully developed theory. Based on our difficulties in assessing the predicted levels of connectedness and potential dimensions using quantitative content analysis, we agree with this perspective. Additionally, our results point to the likely importance of social identity and intergroup dynamics for shaping and understanding reorganization and adaptation processes in social systems where distinct groups of people are debating policy choices. However, it is important to remember that our case study focused on recreational fisheries governance and did not involve ecological change and the interaction of ecology and society. Thus, comparisons with previous studies on adaptive cycles in SES (Peterson 2000, Brunk 2002, Cocks 2003, Seixas and Berkes 2003, Allison and Hobbs 2004, Bohensky 2008, González et al. 2008, Beier et al. 2009) are challenging. Nevertheless, we suggests that in cases similar to ours, conceptual refinements of the adaptive cycle heuristic based on disciplinary social science theories, e.g., social identity theory, may help to better understand transition and transformation in social systems (sensu Abel et al. 2006). Future research is needed in terms of development of indicators of connectedness and potential in social systems and how different or similar these dimensions are to the overarching concept of social capital. Overall, we think that the adaptive cycle heuristic remains useful to describe processes of change in social systems and we recommend other applications to social systems to assess the connectedness and potential dimensions based on other data sources than cover articles, e.g., investigation of actual governance change processes and associated indicator variables instead of focusing on published communication dynamics only.

Responses to this article can be read online at:

http://www.ecologyandsociety.org/voll6/iss2/art3/responses/

\section{Acknowledgments:}

Funding for this study was provided through the project Adaptfish granted to RA by the GottfriedWilhelm-Leibniz-Community (www.adaptfish.igbberlin.de). The finalization of the project received further funding by the German Ministry for Education and Research (BMBF) within the project "Besatzfisch" (www.besatzfisch.de) in the Program for Social-Ecological Research (grant no. 01UU0907). Julia Rickmann was the second coder and helped with the data collection and analysis. The authors are grateful for insights and comments of Elinor Ostrom, Xavier Basurto, Maja Schlüter, Melf-Hinrich Ehlers, Jes Weigelt, and Cristiana Simão Seixas on earlier versions of this paper. The manuscript also benefited from the excellent comments of three anonymous reviewers.

\section{LITERATURE CITED}

Abel, N., D. H. M. Cumming, and J. M. Anderies. 2006. Collapse and reorganization in socialecological systems: questions, some ideas, and policy implications. Ecology and Society 11(1): 17. [online] URL: http://www.ecologyandsociety.org/voll1/ iss1/art17/.

Adger, W. N., P. M. Kelly, A. Winkels, L. Q. Huy, and C. Locke. 2002. Migration, remittances, livelihood trajectories, and social resilience. Ambio 31(4):358-366. 
Alcorn, J. B., J. Bamba, S. Masiun, I. Natalia, and A. G. Royo. 2003. Keeping ecological resilience afloat in cross-scale turbulence: an indigenous social movement navigates change in Indonesia. Pages 299-327 in F. Berkes, J. Colding, and C. Folke, editors. Navigating social-ecological systems: building resilience for complexity and change. Cambridge University Press, Cambridge, UK.

Alesina, A., and N. Fuchs-Schündeln. 2007. Goodbye Lenin (or not)? The effect of communism on people's preferences. American Economic Review 97(4):1507-1528.

Allison, H. E., and R. J. Hobbs. 2004. Resilience, adaptive capacity, and the "Lock-in Trap" of the Western Australian agricultural region. Ecology and Society 9(1): 3. [online] URL: http://www.ecol ogyandsociety.org/vol9/iss1/art3/.

Anderies, J. M., M. A. Janssen, and E. Ostrom. 2004. A framework to analyze the robustness of socialecological systems from an institutional perspective. Ecology and Society 9(1): 18. [online] URL: http:// www.ecologyandsociety.org/vol9/iss 1/art18/.

Arlinghaus, R. 2006. Overcoming human obstacles to conservation of recreational fishery resources, with emphasis on central Europe. Environmental Conservation 33(1):46-59.

Arlinghaus, R., T. Mehner, and I. G. Cowx. 2002. Reconciling traditional inland fisheries management and sustainability in industrialized countries, with emphasis on Europe. Fish and Fisheries 3 (4):261-316.

Beier, C. M., A. L. Lovecraft, and F. S. Chapin, III. 2009. Growth and collapse of a resource system: an adaptive cycle of change in public lands governance and forest management in Alaska. Ecology and Society 14(2): 5. [online] URL: http://www.ecology andsociety.org/vol14/iss2/art5/.

Berkes, F., and C. Folke, editors. 1998. Linking social and ecological system: management practices and social mechanisms for building resilience. Cambridge University Press, Cambridge, UK.

Biggs, R., F. R. Westley, and S. R. Carpenter. 2010. Navigating the back loop: fostering social innovation and transformation in ecosystem management. Ecology and Society 15(2): 9. [online] URL: http://www.ecologyandsociety.org/vol15/iss2/ art9/.

Bohensky, E. L. 2008. Discovering resilient pathways for South African water management: two frameworks for a vision. Ecology and Society 13(1): 19. [online] URL: http://www.ecologyandsociety.org/ vol13/iss1/art19/.

Brunk, G. G. 2002. Why do societies collapse? A theory based on self-organized criticality. Journal of Theoretical Politics 14(2):195-230.

Bunce, M., L. Mee, L. D. Rodwell, and R. Gibb. 2009. Collapse and recovery in a remote small island - a tale of adaptive cycles or downward spirals? Global Environmental Change 19 (2):213-226.

Carpenter, S., B. Walker, J. M. Anderies, and N. Abel. 2001. From metaphor to measurement: resilience of what to what? Ecosystems 4 (8):765-781.

Chapin, F. S., III, S. R. Carpenter, G. P. Kofinas, C. Folke, N. Abel, W. C. Clark, P. Olsson, D. M. Stafford Smith, B. Walker, O. R. Young, F. Berkes, R. Biggs, J. M. Grove, R. L. Naylor, E. Pinkerton, W. Steffen, and F. J. Swanson. 2010. Ecosystem stewardship: sustainability strategies for a rapidly changing planet. Trends in Ecology and Evolution 25(4):241-249.

Cocks, K. D. 2003. Deep futures: our prospects for survival. University of New South Wales Press, Sydney, Australia.

Coleman, J. S. 1988. Social capital in the creation of human capital. American Journal of Sociology 94(Supplement):95-120.

Cumming, G. S., and J. Collier. 2005. Change and identity in complex systems. Ecology and Society 10(1): 29. [online] URL: http://www.ecologyandso ciety.org/vol10/iss1/art29/.

Daedlow, K., T. D. Beard, Jr., and R. Arlinghaus. 2011. A property rights-based view on management of inland recreational fisheries: contrasting common and public fishing rights regimes in Germany and the United States. In A. Loftus, R. Arlinghaus, T. D. Beard, Jr., editors. Proceedings of the 5th World Recreational Fishing Conference, 
American Fisheries Society Symposium, American Fisheries Society, Bethesda, Maryland, USA, in press.

Davidson, D. J. 2010. The applicability of the concept of resilience to social systems: some sources of optimism and nagging doubts. Society \& Natural Resources 23(12):1135-1149.

Deutscher Anglerverband (DAV). 1990. DAVInfo: Zusammenarbeit zwischen dem DAV und dem VDSF entwickelt sich gut. Fisch und Fang 6:1.

Deutscher Anglerverband (DAV). 1992. Mitteilungen des Deutschen Anglerverbandes: Standortbestimmung. Rute und Rolle 9:1.

Deutscher Anglerverband (DAV). 2004. Festschrift50 Jahre Deutscher Anglerverband. Ein erfolgreiches Kapitel in der Geschichte der deutschen Anglerschaft. DAV e.V., Berlin, Germany.

Dovidio, J. F., T. Saguy, and N. Shnabel. 2009. Cooperation and conflict within groups: bridging intragroup and intergroup processes. Journal of Social Issues 65(2):429-449.

Fischer, R., J. Maes, and M. Schmitt. 2007. Tearing down the 'Wall in the head'? Culture contact between Germans. International Journal of Intercultural Relations 31(2):163-179.

Folke, C., T. Hahn, P. Olsson, and J. Norberg. 2005. Adaptive governance of social-ecological systems. Annual Review of Environment and Resources 30:441-473.

Ford, D., L. Gadde, H. Hakansson, A. Lundgren, I. Snehota, P. Turnbull, and D. Wilson. 1998. Managing business relationships. John Wiley, New York, USA.

Früh, W. 2007. Inhaltsanalyse. UVK Verlagsgesellschaft $\mathrm{mbH}$, Konstanz, Germany.

Fuchs-Schündeln, N., and M. Schündeln. 2005. Precautionary savings and self-selection: evidence from the German reunification "experiment." Quarterly Journal of Economics 120(3):1085-1120.

Gläser, J., and G. Laudel. 2004. Experteninterviews und qualitative Inhaltsanalyse als Instrumente rekonstruierender Untersuchungen. VS Verlag für Sozialwissenschaften, Wiesbaden, Germany.
González, J. A., C. Montes, J. Rodríguez, and W. Tapia. 2008. Rethinking the Galapagos Islands as a complex social-ecological system: implications for conservation and management. Ecology and Society 13(2): 13. [online] URL: http://www.ecologyandso ciety.org/vol13/iss2/art13/.

Gunderson, L. H., and C. S. Holling, editors. 2002. Panarchy: understanding transformations in human and natural systems. Island Press, Washington, D.C., USA.

Gunderson, L. H., C. S. Holling, and G. D. Peterson. 2002. Surprises and sustainability: cycles of renewal in the Everglades. Pages 315-332 in L. H. Gunderson and C. S. Holling, editors. Panarchy: understanding transformations in human and natural systems. Island Press, Washington, D.C., USA.

Haase, H. 2000. Faszination Fisch. Geschichtliches zum Fisch und seinem Fang. Findling, Neuenhagen, Germany.

Holling, C. S. 1986. The resilience of terrestrial ecosystems; local surprise and global change. Pages 292-317 in W. C. Clark and R. E. Munn, editors. Sustainable development of the biosphere. Cambridge University Press, Cambridge, UK.

Holling, C. S. 2001. Understanding the complexity of economic, ecological, and social systems. Ecosystems 4(5):390-405.

Holling, C. S., and L. H. Gunderson. 2002. Resilience and adaptive cycles. Pages 25-62 in L. H. Gunderson and C. S. Holling, editors. Panarchy: understanding transformations in human and natural systems. Island Press, Washington, D.C., USA.

Holsti, O. R. 1969. Content analysis for the social sciences and humanities. Reading, Massachusetts, USA.

Janssen, M. A., J. M. Anderies, and E. Ostrom. 2007. Robustness of social-ecological systems to spatial and temporal variability. Society \& Natural Resources 20(4):307-322.

Kessler, T., and S. Hollbach. 2005. Group-based emotions as determinants of ingroup identification. Journal of Experimental Social Psychology 41 (6):677-685. 
Lebel, L., J. M. Anderies, B. Campbell, C. Folke, S. Hatfield-Dodds, T. P. Hughes, and J. Wilson. 2006. Governance and the capacity to manage resilience in regional social-ecological systems. Ecology and Society 11(1): 19. [online] URL: http: //www.ecologyandsociety.org/vol11/iss1/art19/.

Luo, Y. 2002. Building trust in cross-cultural collaborations: towards a contingency perspective. Journal of Management 28(5):669-694.

Mau, G., and D. Müller. 1998. Fischereirecht in der Bundesrepublik, Betrachtung der letzten 50 Jahre. Pages 409-412 in Verband Deutscher Fischereiverwaltungsbeamter und Fischereiwissenschaftler e. V., editors. 50 Jahre Fischerei in Deutschland 1948-1998. VDFF, Nürnberg, Germany.

Mikulin, B. 1992. Mitteilungen des Deutschen Anglerverbandes: Präzisierung. Rute und Rolle 8:1.

Newton, K. 2007. Social and political trust. Pages 342-361 in R. Dalton and H.-D. Klingemann, editors. The Oxford handbook of political behavior. Oxford University Press, New York, USA.

Nkhata, A. B., C. M. Breen, and W. A. Freimund. 2008. Resilient social relationships and collaboration in the management of social-ecological systems. Ecology and Society 13(1): 2. [online] URL: http:// www.ecologyandsociety.org/vol13/iss1/art2/.

Olsson, P., C. Folke, and F. Berkes. 2004. Adaptive comanagement for building resilience in socialecological systems. Environmental Management 34 (1):75-90.

Olsson, P., C. Folke, and T. P. Hughes. 2008. Navigating the transition to ecosystem-based management of the Great Barrier Reef, Australia. Proceedings of the National Academy of Sciences of the USA 105(28):9489-9494.

Olsson, P., L. H. Gunderson, S. R. Carpenter, P. Ryan, L. Lebel, C. Folke, and C. S. Holling. 2006. Shooting the rapids: navigating transitions to adaptive governance in social-ecological systems. Ecology and Society 11(1): 18. [online] URL: http: //www.ecologyandsociety.org/vol11/iss1/art18/.

Peterson, G. 2000. Political ecology and ecological resilience: an integration of human and ecological dynamics. Ecological Economics 35(3):323-336.
Pretty, J. 2003. Social capital and the collective management of resources. Science 302(5652):1912-1914.

Pretty, J., and H. Ward. 2001. Social capital and the environment. World Development 29(2):209-227.

Rowley, J. 1999. Working with social capital. Department for International Development, London, UK.

Schwandt, B. 1991. DAV-Info: Die Weichen sind gestellt. Fisch und Fang 4:1-2.

Seixas, C. S., and F. Berkes. 2003. Dynamics of social-ecological changes in a lagoon fishery in southern Brazil. Pages 271-298 in F. Berkes, J. Colding, and C. Folke, editors. Navigating socialecological systems: building resilience for complexity and change. Cambridge University Press, Cambridge, UK.

Smit, B., and J. Wandel. 2006. Adaptation, adaptive capacity and vulnerability. Global Environmental Change 16(3):282-292.

Tajfel, H. 1982. Social psychology of intergroup relations. Annual Review of Psychology 33:1-39.

Tajfel, H., and J. Turner. 1979. An integrative theory of intergroup conflict. Pages 33-47 in W. Austin and S. Worchel, editors. The social psychology of intergroup relations. Brooks/Cole, Monterey, California, USA.

Trosper, R. L. 2003. Policy transformations in the US forest sector, 1970-2000: implications for sustainable use and resilience. Pages 328-351 in F. Berkes, J. Colding, and C. Folke, editors. Navigating social-ecological systems: building resilience for complexity and change. Cambridge University Press, Cambridge, UK.

Walker, B. H., L. H. Gunderson, A. P. Kinzig, C. Folke, S. R. Carpenter, and L. Schultz. 2006. A handful of heuristics and some propositions for understanding resilience in social-ecological systems. Ecology and Society 11(1): 13. [online] URL: http://www.ecologyandsociety.org/vol11/iss1/ $\underline{\operatorname{art13/}}$.

Walker, B. H., and R. L. Lawson. 2006. Case studies in resilience: fifteen social-ecological systems across continents and societies. Appendix to the Ecology and Society Special Feature Exploring 
Resilience in Social-Ecological Systems. Resilience Alliance. [online] URL: http://www.resalliance.org /1613.php.

Westley, F. 1995. Governing design: the management of social systems and ecosystems design. Pages 391-427 in C. S. Holling and S. S. Light, editors. Barriers and bridges to the renewal of ecosystems and institutions. Columbia University Press, New York, New York, USA.

Westley, F., S. R. Carpenter, W. A. Brock, C. S. Holling, and L. H. Gunderson. 2002. Why systems of people and nature are not just social and ecological systems. Pages 103-120 in L. H. Gunderson and C. S. Holling, editors. Panarchy: understanding transformation in human and natural systems. Island Press, Washington, D.C., USA.

Williamson, O. E. 2002. The theory of the firm as governance structure: from choice to contract. Journal of Economic Perspective 16(3):171-195.

Winkel, M. 1998. Angelfischerei in der DDR. Pages 193-200 in Verband Deutscher Fischereiverwaltungsbeamter und Fischereiwissenschaftler e.V., editors. Jubiläumsschrift zum 50-jährigen Bestehen des Verbandes. Verband Deutscher Fischereiverwaltungsbeamter und Fischereiwissenschaftler e.V., Nürnberg, Germany.

Worchel, S. 2005. Culture's role in conflict and conflict management: some suggestions, many questions. International Journal of Intercultural Relations 29(6):739-757. 